Research Article

\title{
Bloating Mechanism of Lightweight Aggregates due to Ramping Rate
}

\author{
Kang Hoon Lee $\mathbb{D}^{1},{ }^{1}$ Jae Hoon Lee $\mathbb{D}^{2},{ }^{2}$ Young Min Wie, ${ }^{2}$ and Ki Gang Lee $\mathbb{D}^{2}$ \\ ${ }^{1}$ Center for Built Environment, Sungkyunkwan University, Suwon 16419, Republic of Korea \\ ${ }^{2}$ Department of Advanced Materials Engineering, Kyonggi University, Suwon 16227, Republic of Korea
}

Correspondence should be addressed to Ki Gang Lee; gglee@kyonggi.ac.kr

Received 1 December 2018; Revised 4 March 2019; Accepted 14 March 2019; Published 17 April 2019

Academic Editor: Zhonghua Yao

Copyright (C) 2019 Kang Hoon Lee et al. This is an open access article distributed under the Creative Commons Attribution License, which permits unrestricted use, distribution, and reproduction in any medium, provided the original work is properly cited.

\begin{abstract}
The purpose of this study was to improve the recycling rate of industrial wastes by investigating the bloating mechanism of artificial lightweight aggregate depending on the ramping rate and time, which is a dynamic parameter in the production of artificial lightweight aggregate. In this study, coal bottom ash and dredged soil at a weight ratio of $1: 1$ from a domestic power plant were used as raw materials. The artificial lightweight aggregates were formed by using an extruder and pelletizer $(\varphi=10 \mathrm{~mm})$ and sintered by rapid sintering, 2-step firing, and normal sintering method. The physical properties of the aggregates such as bulk density, water absorption ratio, and microstructure of cross section are investigated with the sintering time and temperature. As the result of bloating and trapping mechanism, black core could be inhibited as the firing time increased at the temperature before surface formation. As a result of firing schedule graphs using least square method, it was possible to manufacture artificial lightweight aggregate with micropores, specific gravity of 1.1 , and absorption rate of $3 \%$ at a heating rate of $27^{\circ} \mathrm{c} / \mathrm{min}$ or less.
\end{abstract}

\section{Introduction}

As a result of the rapid national economic and industrial growth, the amount of industrial waste according to such development is continuously increasing. Among various industrial wastes with different characteristics, the amount of coal ash generated from the thermal power generation, which accounts for more than $30 \%$ of Korea's power generation, was about 9 million tons in 2010, but it is expected to increase to 14 million tons in 2017 due to increased generation of coal ash resulting from the construction of additional power plants since 2010 [1-3]. Depending on the characteristics, coal ash can be divided into two categories, fly ash and bottom ash, and fly ash, which accounts for $70 \sim 85 \%$ of the coal ash, is actively recycled as a raw material for concrete admixture and cement. However, in the case of bottom ash, only a part of it is used as a construction fill materials, and when it is used as an aggregate in concrete, there is a limitation in recycling for the quality problems resulting from the workability, which is due to the interlocking phenomenon and management of water content by surface pore [4]. In addition, dredged soil generated during dredging reaches 46 million tons per year, but most of it is treated by landfilling and ocean dumping, so it is urgent to make stabilization and recycling [5-7]. Recently, studies on the production of lightweight aggregate using waste containing coal bottom ash have been actively carried out. [8-10]. Liao et al. [11] prepared aggregates using sediment of reservoir. Yang et al. [12] manufactured aggregates using low-silicon iron tailings, fly ash, and powdery quartz sand. Li et al. [13] produced lightweight aggregates using slate wastes. These various wastes were utilized, and various methods of sintering were used. Riley [14] and Kang and Kang [15] used a temperature elevation sintering method, and Lee $[16,17]$ used rapid sintering. And the aggregate was sintered in the study of Lee [18] by the two-stage sintering method. A variety of calcining methods have been used, and the methodology for producing aggregates has not been well addressed. In general, lightweight aggregate is lightened by bloating when it is fired, and it requires generation of gas for 
foaming and surface which can collect the formed gas $[19,20]$. The bubbling gas is generated by the oxidation of the organic matter and carbon existing inside the reducing atmosphere, where the reaction with external oxygen is blocked during the aggregate firing [21]. Unlike the artificial lightweight aggregates that are manufactured using the existing natural raw materials with low refractoriness, for lightening of the weight, sintering at a high temperature is necessary when artificial lightweight aggregate is produced using recycled resources with high refractivity. Therefore, it is difficult to control the formation rate of the surface and the generation rate of the foaming gas. Furthermore, the formation of the surface for gas collection can be defined as the surface densification, caused by the reduced pore size, which results from the viscous behavior generated in the low melting point compound. In other words, the rate of control of the two reactions determines the bloating behavior of the artificial lightweight aggregate.

There are two main purposes of this study. First, the change of the bloating mechanism by the sintering method of the aggregate is investigated. For this purpose, we produced and evaluated aggregates by rapid sintering, two-step sintering, and normal sintering. Secondly, based on the experimental results, the applicability of the bloating mechanism is predicted in the actual rotary kiln sintering condition.

\section{Materials and Methods}

2.1. Materials. The raw materials used in this study were a mixture of coal bottom ash (B/A), which was discharged after burning bituminous coal in $\mathrm{Y}$ thermal power plant, and dredged soil (D/S) in $1: 1$ ratio by weight. The raw material was pulverized to less than 200 mesh using a pin mill. The chemical composition of the pulverized raw material was analyzed using XRF (ZSR-100e, Rigaku, Tokyo, Japan). The phase of the raw material was analyzed by XRD (Miniflexll, Rigaku, Tokyo, Japan). Plastic index (PI) of dredged soil and experimental mixture (B/A: 50, D/S: 50) was measured by KS F 2304 test method [22].

2.2. Manufacturing of Artificial Lightweight Aggregate. In order to produce artificial lightweight aggregate, the dredged soil, which is inorganic plasticizer, and coal bottom ash were mixed at a weight ratio of $1: 1$, and the mixture was pulverized to less than 200 mesh using a pin mill (TOP, Korea Mechanical Engineering, Changwon, Korea). The pulverized mixture was set to a moisture content of $20 \%$, and artificial lightweight aggregate was formed into a size of about $10 \mathrm{~mm}$ using an extruder (GRN05, VANHO, Chilgok, Korea). The discharged product was rotated for 5 minutes at $40 \mathrm{rpm}$ and $50^{\circ}$ using a pelletizer (WPP 700, Woongbi Machinery, Cheonan, Korea), and resulting aggregate was dried at $105^{\circ} \mathrm{C}$ for 24 hours using a dryer.

In order to maximize the surface densification, rapid sintering method, where the discharge is done after maintaining the maximum temperature for a certain period of time, is used. Also, to control the content of the foaming gas, a two-stage firing method was used where temperature before the formation of liquid on the surface is maintained for a certain period of time, followed by the maintenance of maximum temperature for a set time before the discharge. Also, for the rotary kiln firing conditions, the normal firing method was used in which the initial temperature was raised from $300^{\circ} \mathrm{C}$ to the maximum temperature. Additives were not used, and the change in physical properties [23] of artificial lightweight aggregate was observed for each firing method. The schedule for each firing method is shown in Figure 1.

\subsection{Theory of Bloating Mechanism}

2.3.1. Black Core Bloating Mechanism. Typical lightweight aggregate is foamed by the black coring phenomenon caused by the reduction of $\mathrm{Fe}_{2} \mathrm{O}_{3}$. The sintering of the aggregate confines the internal gas. Oxidation of organic substances and carbon in the interior creates a reducing atmosphere. The chemical equation for this is as follows [24-26]:

$$
\begin{gathered}
3 \mathrm{Fe}_{2} \mathrm{O}_{3} \cdot 2 \mathrm{FeO} \cdot \mathrm{Fe}_{2} \mathrm{O}_{3}+\frac{1}{2 \mathrm{O}_{2}} \\
3 \mathrm{Fe}_{2} \mathrm{O}_{3}+\mathrm{C} \longrightarrow 2 \mathrm{Fe}_{3} \mathrm{O}_{4}+\mathrm{CO} \\
\mathrm{Fe}_{3} \mathrm{O}_{4}+\mathrm{C} \longrightarrow 3 \mathrm{FeO}+\mathrm{CO}
\end{gathered}
$$

Reactions (1) to (3) explain the reduction reaction of $\mathrm{Fe}_{2} \mathrm{O}_{3}$ by $\mathrm{CO}$. The $\mathrm{CO}$ gas generated in the reducing atmosphere raises the internal pressure. The resulting $\mathrm{FeO}$ also lowers the viscosity of the inside of aggregate to form a liquid phase and promotes viscous behavior. In other words, the velocity control of the two reactions determines the bloating of the artificial lightweight aggregate. In this case, the pores are concentrated in the central part.

\subsubsection{Micropore Generation and Growth Mechanism.} Kose and Bayer [27] suggested that the bloating mechanism of foamed glass can be divided into the following three stages.

(1) Gas generation inside the body

(2) Pore creation and bonding by internal pressure

(3) Expansion of pores due to pressure difference between small pores and large pores

Most of the foaming takes place in stages 1 and 2 and is lightweight. In step 3, pore growth was achieved. In the bloating mechanism, Kose and Bayer [27] claimed gas pressure and viscous behavior of the material determine the properties. This is similar to the black core mechanism described above. However, unlikely, in the black core mechanism, chemical changes such as reduction of $\mathrm{Fe}_{2} \mathrm{O}_{3}$ do not occur. In this case, small pores are distributed evenly inside the aggregate. Therefore to predict the bloating mechanism of lightweight aggregate, the ramping rate is the most important factor. Figure 2 shows the flow diagram of the experimental routes. 


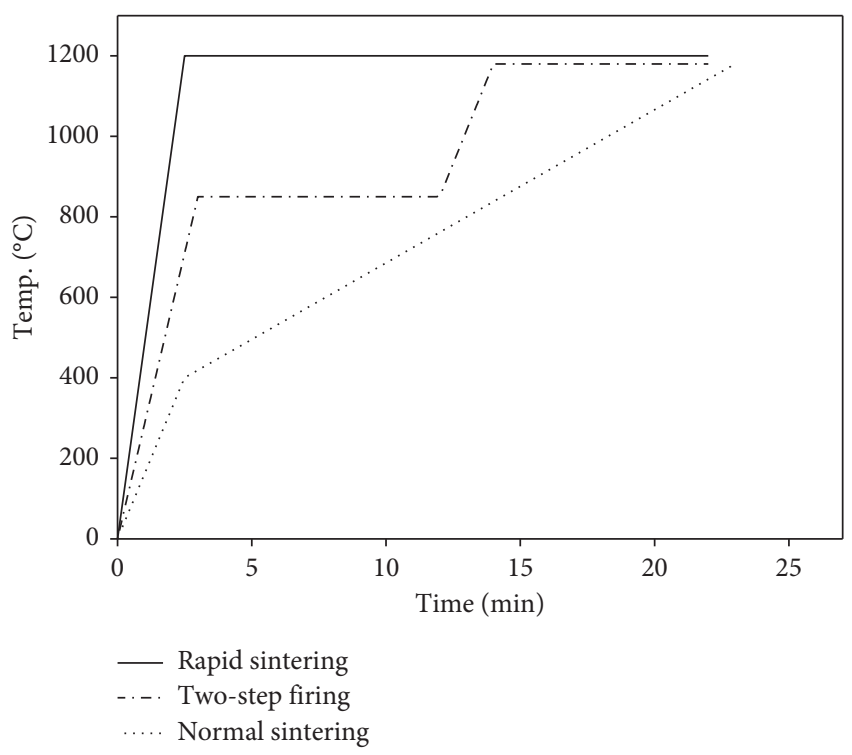

FIGURE 1: Schedule of heating by different ramping rates.

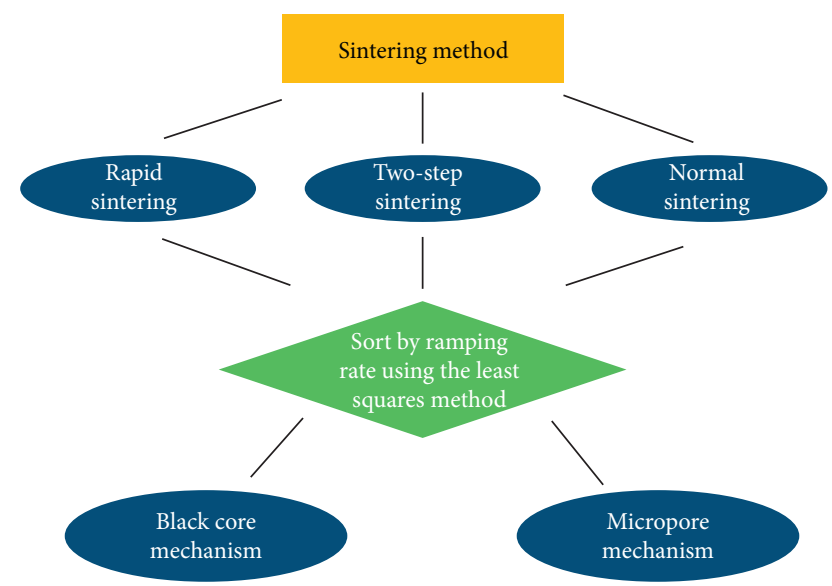

FIGURE 2: Flow diagram of the experimental routes.

\section{Results and Discussion}

3.1. Raw Materials. Table 1 shows the results of the plastic limit (PL) and liquid limit (LL) of the raw materials. Moreno-Maroto et al. [28] classified clay by PI/LL. The PI/LL value of dredged soil was 0.43 and the value of 0.22 for the sample with $50 \%$ coal bottom ash. According to MorenoMaroto and Alonso-Azcárate [28] classification, dredged soil is classified as silty clay or sandy clay depending on the content of sand, and it is a region where the formation is sufficient. The addition of coal bottom ash reduces the plasticity and turns into a soil with little toughness.

Figure 3 shows the XRD measurement results of the raw materials. Dredged soil consists of quartz, albite, muscovite, etc., which are easily observed in common soils. In the case of coal bottom ash, it was basically amorphous, and cristobalite and mullite phases were weakly observed. Table 2 shows the chemical composition of the raw materials. The results were plotted on Riley [14] and Cougny diagrams [29] (Figure 4). The dredged soil was found to satisfy both the
Table 1: Plastic limit (PL), liquid limit (LL), and plasticity index (PI) of raw materials.

\begin{tabular}{lccc}
\hline Items & $\begin{array}{c}\text { PL (plastic } \\
\text { limit) }\end{array}$ & $\begin{array}{c}\text { LL (liquid } \\
\text { limit) }\end{array}$ & $\begin{array}{c}\text { PI (plasticity } \\
\text { index) }\end{array}$ \\
\hline $\begin{array}{l}\text { Dredged soil } \\
\begin{array}{l}\text { Coal bottom } \\
\text { ash 50\% }\end{array}\end{array}$ & 20 & 35 & 15 \\
\begin{tabular}{l} 
Dredged soil 50\% \\
\hline
\end{tabular}
\end{tabular}

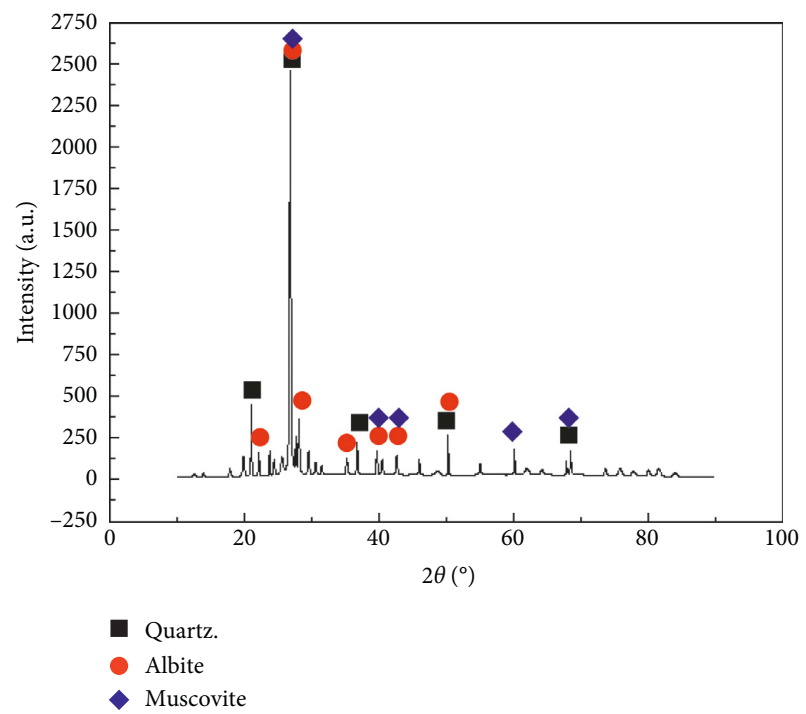

(a)

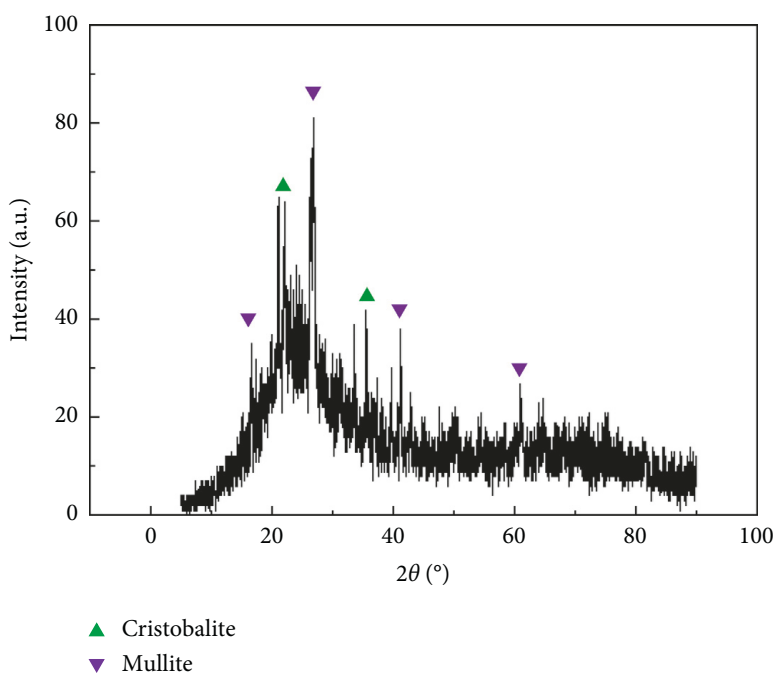

(b)

FIgURE 3: XRD analysis of raw materials. (a) Dredged soil. (b) Coal bottom ash.

Riley [14] diagram and the foam region of the Cougny [29] diagram. However, the amount of $\mathrm{Fe}_{2} \mathrm{O}_{3}$ was somewhat lower and appeared close to the critical region. In the case of B/A, both Riley diagram [14] and Cougny diagram [29] were not satisfied. The mixture of two raw materials (B/A $50: \mathrm{D} / \mathrm{S}$ 50) satisfies the Riley diagram but not the Cougny diagram. Although the mixture does not satisfy both diagrams well, 
TABLE 2: Chemical compositions of raw material.

\begin{tabular}{lcc}
\hline & Coal bottom ash & Dredged soil \\
\hline Ig. loss & 0 & 4.04 \\
$\mathrm{SiO}_{2}$ & 62.03 & 71.00 \\
$\mathrm{Al}_{2} \mathrm{O}_{3}$ & 25.40 & 14.24 \\
$\mathrm{Fe}_{2} \mathrm{O}_{3}$ & 4.14 & 3.78 \\
$\mathrm{CaO}$ & 1.00 & 0.78 \\
$\mathrm{MgO}$ & 0.94 & 0.18 \\
$\mathrm{Na} \mathrm{N}_{2} \mathrm{O}$ & 0.08 & 2.49 \\
$\mathrm{~K}_{2} \mathrm{O}$ & 3.23 & 2.67 \\
$\mathrm{TiO}_{2}$ & 0.84 & 0.79 \\
$\mathrm{ZrO}_{2}$ & 0 & 0 \\
$\mathrm{P}_{2} \mathrm{O}_{5}$ & 0.12 & 0.03 \\
$\mathrm{Cr}_{2} \mathrm{O}_{3}$ & 0.02 & 0 \\
$\mathrm{MnO}$ & 0.03 & 0 \\
$\mathrm{C}$ & 1.74 & 0 \\
Total & 100 & 100 \\
\hline
\end{tabular}

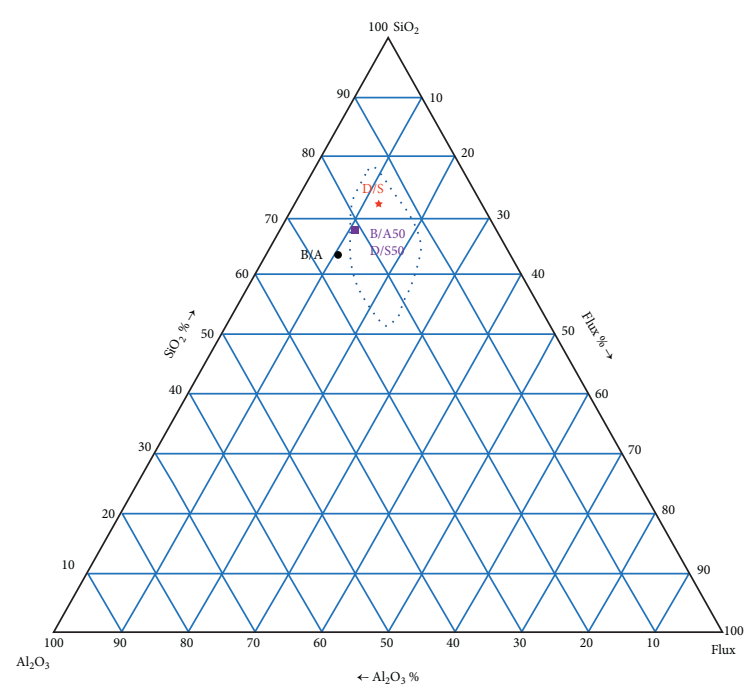

(a)

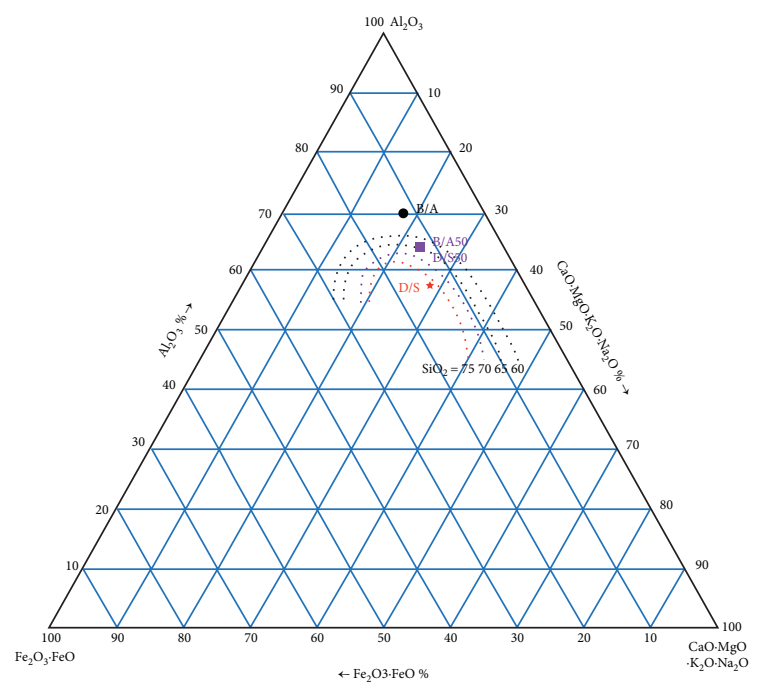

(b)

FIgURE 4: The raw material and the mixture are plotted in a tripletstate diagram. (a) Riley diagram [14]. (b) Cougny diagram [22]. according to Dondi et al. [8], the use of waste as a lightweight aggregate can be lightened even if it deviates from chemical composition.

3.2. Lightweight Properties of Artificial Lightweight Aggregate by Controlling the Reaction Rate. In this study, we tried to control the reaction rate of the foamed gas and the densification of the surface of the artificial lightweight aggregate. In order to control such conditions, the surface densification was maximized by using the rapid sintering method where the input temperature and discharge temperature are the same. Also, lightweight characteristic of lightweight aggregate was confirmed by controlling the amount of gas trapped in the aggregate by dividing the firing steps into two: controlling the amount of foam gas using the two-step firing method ( $1^{\text {st }}$ step) and densifying the surface ( $2^{\text {nd }}$ step). Furthermore, the foaming conditions and the trapping behavior applied to the actual process through the normal sintering method were confirmed, and the respective experimental conditions are shown in Table 3.

Figure 5 is a graph of bulk density and water absorption ratio of an artificial lightweight aggregate produced by a rapid sintering method. Bloating was started at $1100^{\circ} \mathrm{C}$, and it shows bulk density of about $1.2 \mathrm{~g} / \mathrm{cm}^{3}$. With the increase of the firing temperature, the bulk density decreased and the water absorption ratio also decreased by $14 \%$. As it can be seen from the cross-sectional image shown in Figure 6, the close pore tends to expand as the firing temperature increases. Also, black core is generated in all aggregates and crack is generated on the outside. This is because of the large amount of foam gas trapped inside the aggregate, which results from the surface densification, and high water absorption ratio was a result of the crack that was caused by the lack of viscous behavior on the surface, which is due to the deficient amount of the liquid phase on the surface.

Figure 7 is a graph of bulk density and water absorption ratio of an artificial lightweight aggregate produced by a twostage firing method at different temperatures. Both bulk density and the water absorption ratio showed similar tendency when the $1^{\text {st }}$ stage temperature was between $600^{\circ} \mathrm{C}$ and $800^{\circ} \mathrm{C}$. Especially at the firing temperature between $1120^{\circ} \mathrm{C}$ and $1160^{\circ} \mathrm{C}$, the firing tendency was observed and the bulk density was between $1.9 \mathrm{~g} / \mathrm{cm}^{3}$ and $2.0 \mathrm{~g} / \mathrm{cm}^{3}$. As the $1^{\text {st }}$ step becomes longer, bulk density gets higher. This is because the organic matter or carbon which makes the reduction state in aggregate is oxidized and gas foaming does not occur in the $2^{\text {nd }}$ step, and the water absorption ratio also tends to be the same. However at the firing temperature $1180^{\circ} \mathrm{C}$ which is the beginning of the liquid phase, bloating was started, and the bulk density was $1.1 \mathrm{~g} / \mathrm{cm}^{3}$ at $1220^{\circ} \mathrm{C}$. In case of the water absorption ratio, same as bulk density result, cracks did not occur, which resulted in the water absorption ratio of less than $10 \%$, and at temperature higher than $1180^{\circ} \mathrm{C}$, where liquid was formed on surface, the absorption rate was within $3 \%$. However, for the aggregate that was fired for 10 minutes with the $1^{\text {st }}$ stage temperature of $900^{\circ} \mathrm{C}$, a high absorption rate was observed unlike the previous results. 
TABLe 3: Experimental conditions.

\begin{tabular}{|c|c|c|c|}
\hline Sintering & Input temperature $\left({ }^{\circ} \mathrm{C}\right)$ & Output temperature $\left({ }^{\circ} \mathrm{C}\right)$ & Sintering time $(\mathrm{min})$ \\
\hline \multirow{3}{*}{ Rapid sintering } & 1100 & 1100 & \multirow{3}{*}{10} \\
\hline & 1140 & 1140 & \\
\hline & 1180 & 1180 & \\
\hline \multirow{6}{*}{ Two-step firing } & & 1120 & \multirow{2}{*}{$10\left(7^{\prime}+3^{\prime}\right)$} \\
\hline & 600 & 1140 & \\
\hline & 700 & 1160 & \multirow{2}{*}{$20\left(14^{\prime}+6^{\prime}\right)$} \\
\hline & 800 & 1180 & \\
\hline & 900 & 1200 & \multirow{2}{*}{$30\left(21^{\prime}+9^{\prime}\right)$} \\
\hline & & 1220 & \\
\hline \multirow{6}{*}{ Normal sintering } & \multirow{6}{*}{300} & 1120 & \multirow{6}{*}{40} \\
\hline & & 1140 & \\
\hline & & 1160 & \\
\hline & & 1180 & \\
\hline & & 1200 & \\
\hline & & 1220 & \\
\hline
\end{tabular}

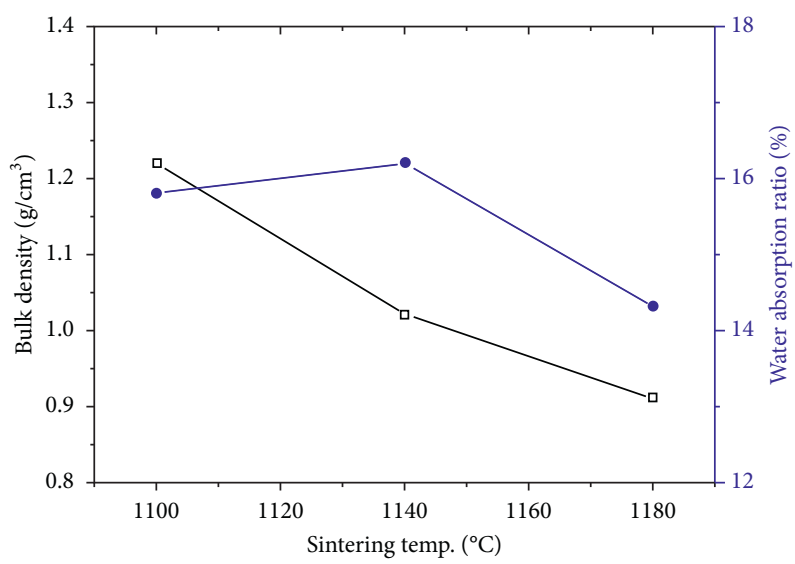

Figure 5: Physical properties of the lightweight aggregate by rapid sintering.

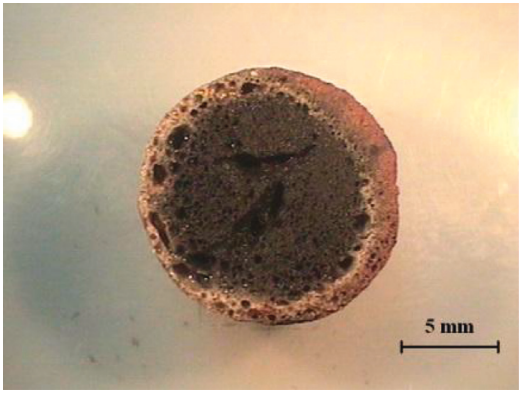

(a)

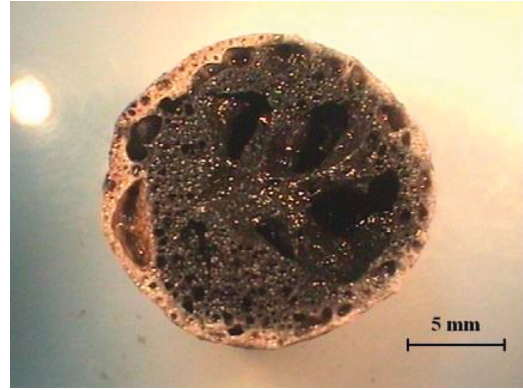

(b)

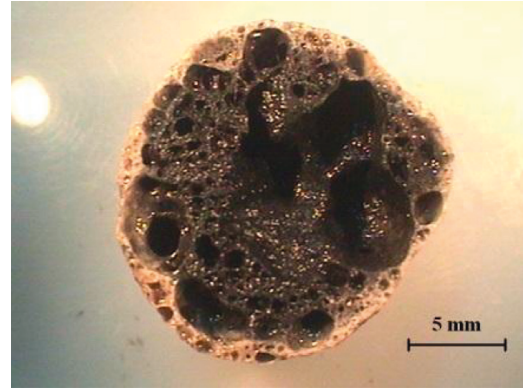

(c)

FIGURE 6: Microstructure image of the lightweight aggregate by rapid sintering. (a) $1100^{\circ} \mathrm{C}$. (b) $1140^{\circ} \mathrm{C}$. (c) $1180^{\circ} \mathrm{C}$.

This is because unlike the aggregates fired at relatively low temperature, the surface capable of trapping the foaming gas is formed, and as a result, the black core is formed which leads to a formation of crack.

\subsection{Identification of Actual Process Conditions by the Normal} Sintering Method. During the production of artificial lightweight aggregate, firing is done at the rotary kiln.
Therefore, because the artificial lightweight aggregate is fired while moving inside the rotary kiln from low temperature to high temperature, the two-stage firing method is divided into low-temperature and high-temperature regions. However, this is not sufficient to confirm the bloating behavior and the trapping behavior applied in actual process conditions. Consequently, the artificial lightweight aggregate was prepared by the normal sintering method, where mixture was input at $300^{\circ} \mathrm{C}$, the input temperature of the 


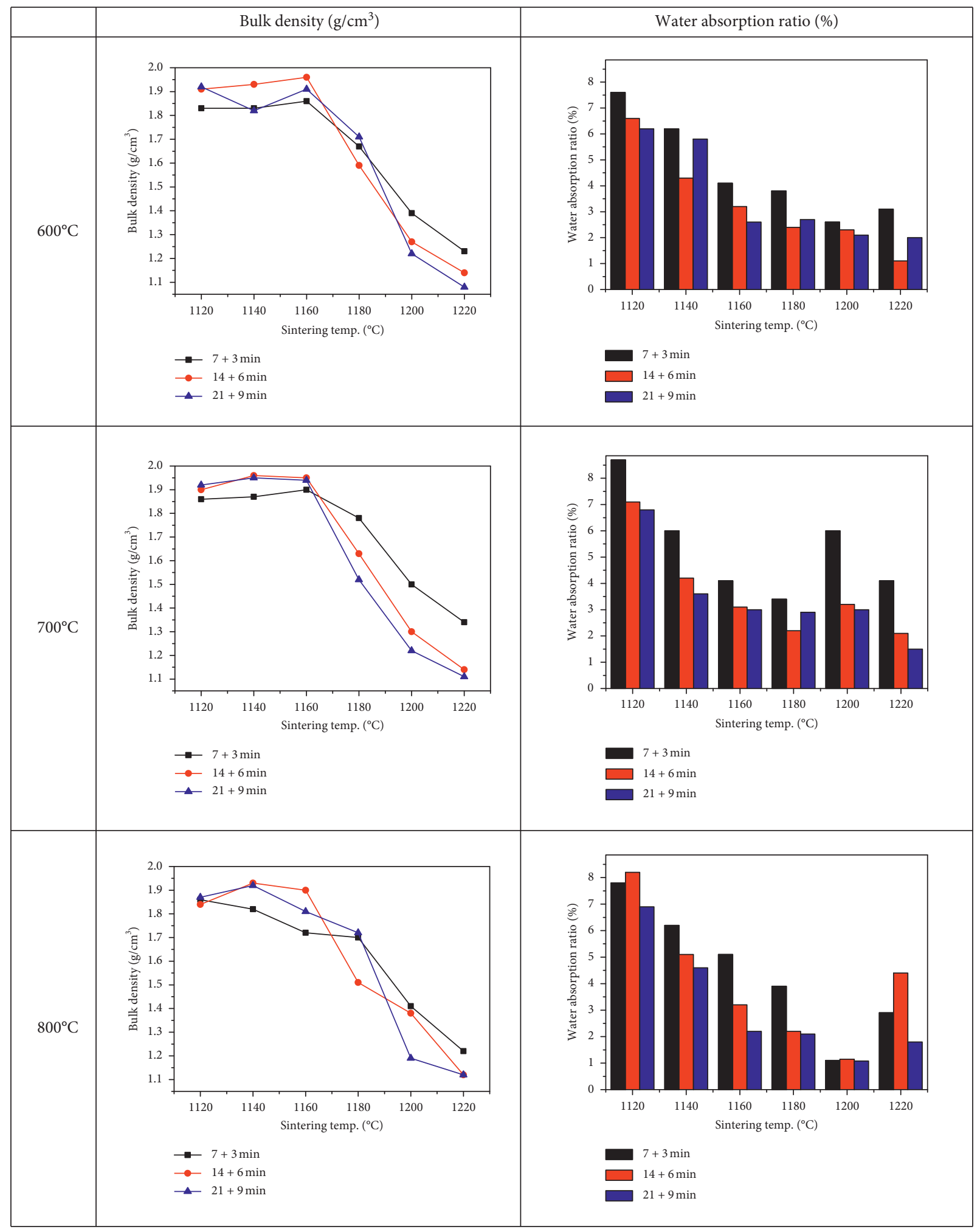

Figure 7: Continued. 


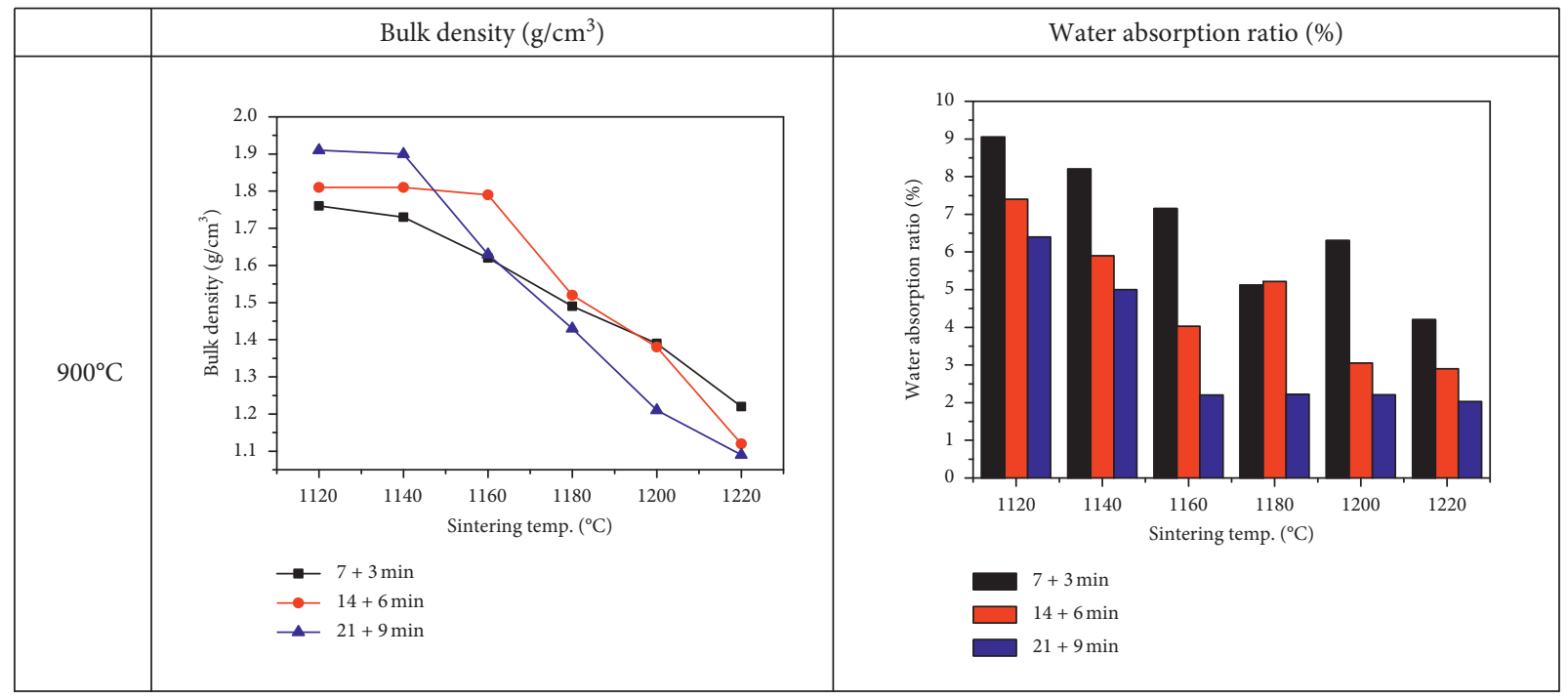

Figure 7: Physical properties of the lightweight aggregate by 2-step firing with a variation in input temperature. Bulk density and water absorption ratio.

rotary kiln used in an actual process, and fired to a desired temperature for a predetermined period of time.

Figure 8 shows the bulk density and water absorption ratio of the artificial lightweight aggregate prepared by the normal sintering method. The bloating does not occur at a temperature of $1120^{\circ} \mathrm{C}$, indicating a bulk density of about $2.0 \mathrm{~g} / \mathrm{cm}^{3}$. However, it can be seen that the bulk density gradually decreases with the increasing firing temperature. Also, it decreased rapidly between 1160 and $1180^{\circ} \mathrm{C}$, to obtain a bulk density of less than $1.5 \mathrm{~g} / \mathrm{cm}^{3}$, and weight reduction was possible. At $1200^{\circ} \mathrm{C}$, a bulk density of about $1.1 \mathrm{~g} / \mathrm{cm}^{3}$ was obtained. When the firing time was 60 minutes, the bulk density was higher than that of 40 minute firing. This is because the gas required for foaming flows out to the outside before the surface is densified, which is due to the longer baking time and longer calcinating time in the low-temperature region.

Figure 9 shows the cross-sectional images of the artificial lightweight aggregate produced using the normal sintering method. The pore size was increased in the temperature between 1160 and $1180^{\circ} \mathrm{C}$, where the bulk density rapidly decreased Also, it was confirmed that the pore was completely expanded in the fired aggregate at $1200^{\circ} \mathrm{C}$, with a bulk density of about $1.1 \mathrm{~g} / \mathrm{cm}^{3}$. In order to predict the bloating behaviors in the rotary kiln, a mass-production condition, the normal sintering method was used. As a result, it was possible to lighten the artificial lightweight aggregate, which did not form cracks outside the aggregate. However, at $1200^{\circ} \mathrm{C}$ or higher, the liquid phase is excessively formed on the surface and the structure tends to collapse, which is not suitable as the rotary kiln firing temperature.

3.4. Identification of Bloating Mechanism by Ramping Rate. According to the results found in the previous experiment, where the bloating mechanism was determined for each firing method, it was found that, when the discharge time for foaming gas before the surface densification and vitrification was controlled by the firing method, the microstructure changes, and bulk density and water absorption ratio characteristics of the lightweight aggregate also change as a result. In this section, the bloating phenomenon according to the ramping rate for specific regions from the previous experiment was identified.

Figure 10 is a graph of the ramping rate according to the firing schedule. The ramping rate was expressed using the least squares method, for each schedule with different firing conditions. For the range between $\mathrm{A}$ and $\mathrm{E}$, the rate of temperature increase was over $35^{\circ} \mathrm{C} / \mathrm{min}$., and black core was formed in all specimens. However, for the range between $\mathrm{F}$ and $\mathrm{J}$, the ramping rate was $27^{\circ} \mathrm{C} / \mathrm{min}$. or less, and micropores were developed which resulted in lightweight. Similar to the result from one of the previous studies, aggregates with a low water absorption ratio of $3 \%$ or less could be obtained.

Table 4 shows the bulk density and microstructure fore different ramping rates. The bulk density decreased with the decrease in the ramping rate, when the ramping rate was $27^{\circ} \mathrm{C} / \mathrm{min}$. or lower, which is the rate at which the micropores are obtained. This is because even at the same firing temperature, a large amount of heat energy is required and therefore supplied, for bloating. This means that it is possible to manufacture artificial lightweight aggregate that has micropores and controlled water absorption ratio, when the aggregate is fired at a temperature ramping rate of $27^{\circ} \mathrm{C} / \mathrm{min}$. or lower.

3.5. Bloating Index and Single Aggregate Crushing Strength of Aggregate. The bloating index (BI) was calculated as the volume changes after heating (prefiring + firing steps), according to the equation $\mathrm{BI}=100 \times\left(d_{2} \times d_{1}\right) / d_{1}$, where $d_{1}$ and $d_{2}$ are the diameters of the granules before and after heating, respectively $[30,31]$. 


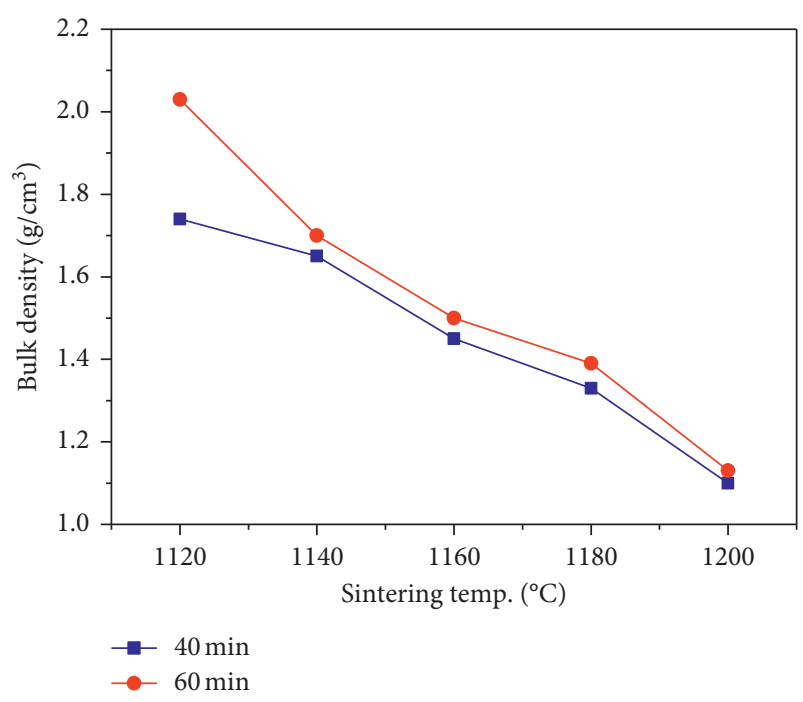

(a)

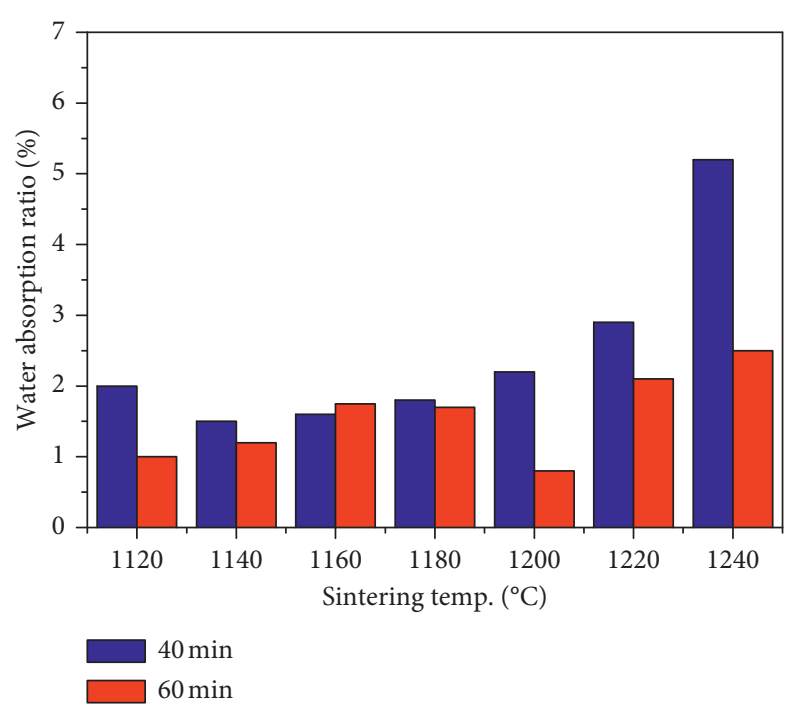

(b)

Figure 8: Physical properties of the lightweight aggregate by normal sintering. (a) Bulk density. (b) Water absorption ratio.

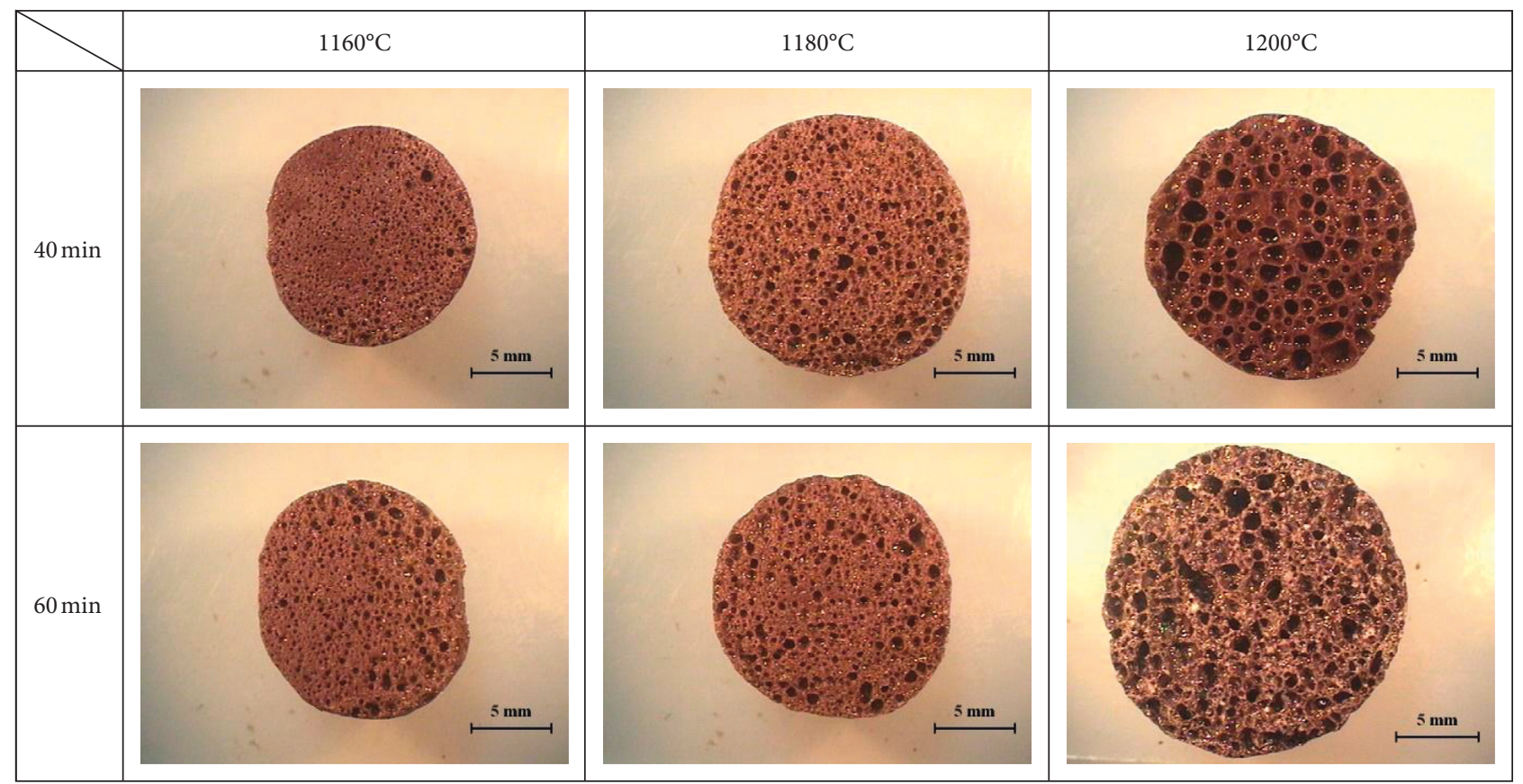

FIGURE 9: Microstructure image of the lightweight aggregate by normal sintering with a variation in output temperature.

The single aggregate crushing strength was measured by using the Universal Testing Machine (DS-001, Daeshin, Namyangju, Korea). The single aggregate crushing strength value $(S)$ was determined according to the equation $S=\left(2.8 P_{\mathrm{c}}\right) /\left(\pi X^{2}\right)$, where $P_{\mathrm{c}}$ is the load at which a rupture occurs and $X$ is the sphere diameter $[32,33]$. The average single aggregate crushing strength was calculated from the tests performed on 15 granules.

The bloating index and single aggregate crushing strength of aggregate were measured.

There are three samples prepared for measurement:

\section{R: rapid sintering at $1100^{\circ} \mathrm{C}$ samples}

D: two-step sintering at $900^{\circ} \mathrm{C}$ for $7 \mathrm{~min}, 1180^{\circ} \mathrm{C}$ for 3 min samples

F: two-step sintering at $900^{\circ} \mathrm{C}$ for $21 \mathrm{~min}, 1180^{\circ} \mathrm{C}$ for 9 min samples

The results of BI measurement are shown in Figure 11. As a result, the $\mathrm{BI}$ of the low-density $\mathrm{R}$ sample was the highest, and the BIs of the D and F were almost the same. When the same raw materials were used, the lower the density, the higher the expansion index. 


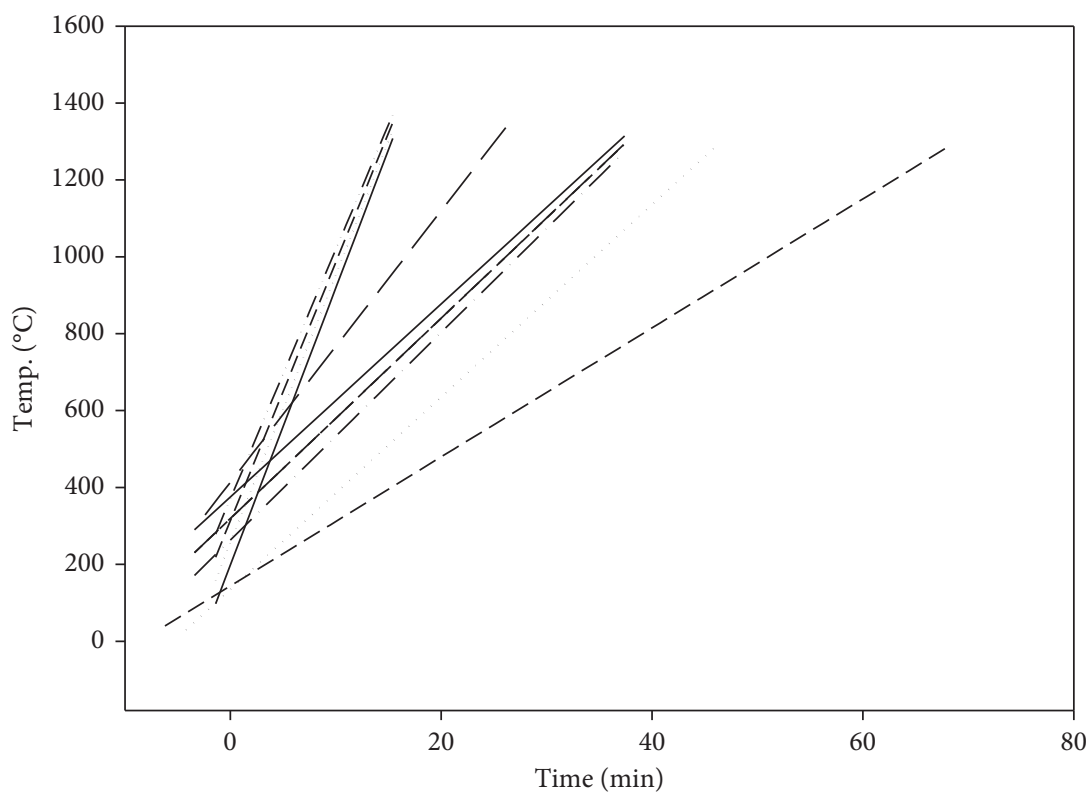

\begin{tabular}{|c|c|c|c|}
\hline & Conditions & Equations & R squared \\
\hline & A: $600^{\circ} \mathrm{C}+1180^{\circ} \mathrm{C}, 10 \mathrm{~min}$ & $Y=72.045 X+198.27$ & 0.7927 \\
\hline & B: $700^{\circ} \mathrm{C}+1180^{\circ} \mathrm{C}, 10 \mathrm{~min}$. & $Y=69.66 X+255.42$ & 0.7698 \\
\hline---- & $\mathrm{C}: 800^{\circ} \mathrm{C}+1180^{\circ} \mathrm{C}, 10 \mathrm{~min}$. & $Y=67.283 X+312.56$ & 0.7268 \\
\hline$-\cdots-\cdots$ & $\mathrm{D}: 900^{\circ} \mathrm{C}+1180^{\circ} \mathrm{C}, 10 \mathrm{~min}$. & $Y=64.901 X+369.70$ & 0.6664 \\
\hline-- & $\mathrm{E}: 900^{\circ} \mathrm{C}+1180^{\circ} \mathrm{C}, 20 \mathrm{~min}$. & $Y=35.3181 X+413.18$ & 0.6080 \\
\hline--- & $\mathrm{F}: 600^{\circ} \mathrm{C}+1180^{\circ} \mathrm{C}, 30 \mathrm{~min}$ & $Y=27.0181 X+263.09$ & 0.7048 \\
\hline--- & $\mathrm{G}: 700^{\circ} \mathrm{C}+1180^{\circ} \mathrm{C}, 30 \mathrm{~min}$. & $Y=26.065 X+319.09$ & 0.6813 \\
\hline 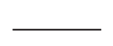 & $\mathrm{H}: 800^{\circ} \mathrm{C}+1180^{\circ} \mathrm{C}, 30 \mathrm{~min}$. & $Y=25.112 X+375.10$ & 0.6401 \\
\hline & I: Firing $40 \mathrm{~min} .\left(300^{\circ} \mathrm{C} \sim 1180^{\circ} \mathrm{C}\right)$ & & \\
\hline
\end{tabular}

FIGURE 10: Heating rate graph with various firing conditions.

Single aggregate crushing strength was measured and shown in Figure 12. The strength of $\mathrm{R}$ aggregate was measured lowest, and $\mathrm{D}$ and $\mathrm{F}$ were measured similarly. This is similar to the density trend. Gonzalez-Corrochano et al. [31] showed that the crush strength of commercial structural aggregates was only $3 \mathrm{MPa}$, indicating that all aggregates of $\mathrm{R}, \mathrm{D}$, and $\mathrm{F}$ have a similar strength to those of commercial structural lightweight aggregates. Wie and Lee [34] also showed that the lower the density, the lower the single aggregate crushing strength.

\section{Conclusion}

In this study, experiments were conducted to confirm the bloating and trapping behaviors of artificial lightweight aggregate, and the results found were listed below:
(1) The mixture of coal bottom ash and dredged soil chemically satisfied the composition of Riley [14] and can be formed by using the extruder as renewable raw materials.

(2) Bloating by black core occurred at $1100^{\circ} \mathrm{C}$ with rapid sintering, and bulk density became $1 \mathrm{~g} / \mathrm{cm}^{3}$ at $1180^{\circ} \mathrm{C}$. However, since the absorption ratio was over $15 \%$, the crushing strength of the lightweight aggregate was about $2.5 \mathrm{MPa}$ which is relatively low strength.

(3) It was possible to control the amount of foaming gas by controlling the firing time and temperature in the temperature region located before the surface formation. Also, as the retention time increased, the tendency for micropore formation was confirmed, and the absorption ratio could be controlled by suppressing the formation of surface cracks. 
TABLE 4: Bulk density and microstructure with ramping rate.

\begin{tabular}{|c|c|c|c|c|c|c|}
\hline No & Firing conditions & $\begin{array}{c}\text { Heating rate } \\
\left({ }^{\circ} \mathrm{C} / \mathrm{min}\right)\end{array}$ & $\begin{array}{c}\text { Bulk density } \\
\left(\mathrm{g} / \mathrm{m}^{3}\right)\end{array}$ & $\begin{array}{c}\text { Water absorption } \\
\text { ratio }(\%) \\
\end{array}$ & $\begin{array}{c}\text { Microstructure image } \\
\text { of cross section }\end{array}$ & Bloating mechanism \\
\hline A & $600^{\circ} \mathrm{C}+1180^{\circ} \mathrm{C} 10 \mathrm{~min}$. & 72 & 1.72 & 4.1 & & Black core \\
\hline B & $700^{\circ} \mathrm{C}+1180^{\circ} \mathrm{C} 10 \mathrm{~min}$ & 69 & 1.75 & 3.8 & & Black core \\
\hline $\mathrm{C}$ & $800^{\circ} \mathrm{C}+1180^{\circ} \mathrm{C} 10 \mathrm{~min}$ & 67 & 1.7 & 4.1 & & Black core \\
\hline $\mathrm{D}$ & $900^{\circ} \mathrm{C}+1180^{\circ} \mathrm{C} 10 \mathrm{~min}$. & 64 & 1.51 & 5.1 & & Black core \\
\hline $\mathrm{E}$ & $900^{\circ} \mathrm{C}+1180^{\circ} \mathrm{C} 20 \mathrm{~min}$. & 35 & 1.53 & 5.2 & & Black core \\
\hline $\mathrm{F}$ & $600^{\circ} \mathrm{C}+1180^{\circ} \mathrm{C} 30 \mathrm{~min}$. & 27 & 1.53 & 2.5 & & Micropore \\
\hline G & $700^{\circ} \mathrm{C}+1180^{\circ} \mathrm{C} 30 \mathrm{~min}$. & 26 & 1.52 & 2.7 & & Micropore \\
\hline $\mathrm{H}$ & $800^{\circ} \mathrm{C}+1180^{\circ} \mathrm{C} 30 \mathrm{~min}$. & 25 & 1.51 & 2.1 & & Micropore \\
\hline I & $300 \sim 1180^{\circ} \mathrm{C}$ normal sintering $40 \mathrm{~min}$. & 25 & 1.3 & 1.8 & & Micropore \\
\hline $\mathrm{J}$ & $300 \sim 1180^{\circ} \mathrm{C}$ normal sintering $60 \mathrm{~min}$. & 16 & 1.32 & 1.7 & & Micropore \\
\hline
\end{tabular}




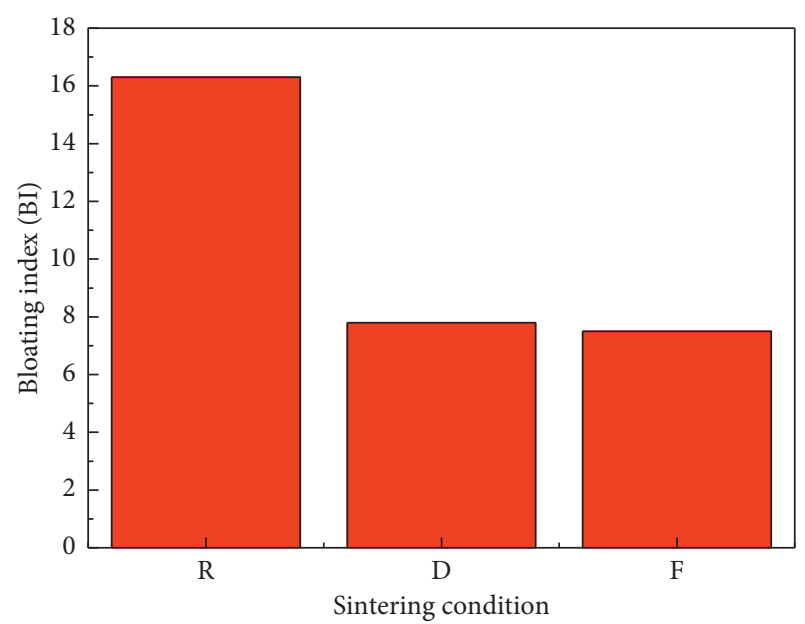

$\mathrm{R}$ : rapid sintering at $1180^{\circ} \mathrm{C}$

D: $900^{\circ} \mathrm{C}-1180^{\circ} \mathrm{C}-10 \mathrm{~min}$

F: $600^{\circ} \mathrm{C}-1180^{\circ} \mathrm{C}-30 \mathrm{~min}$

FIGURE 11: Bloating index (BI) of the sintering aggregate.

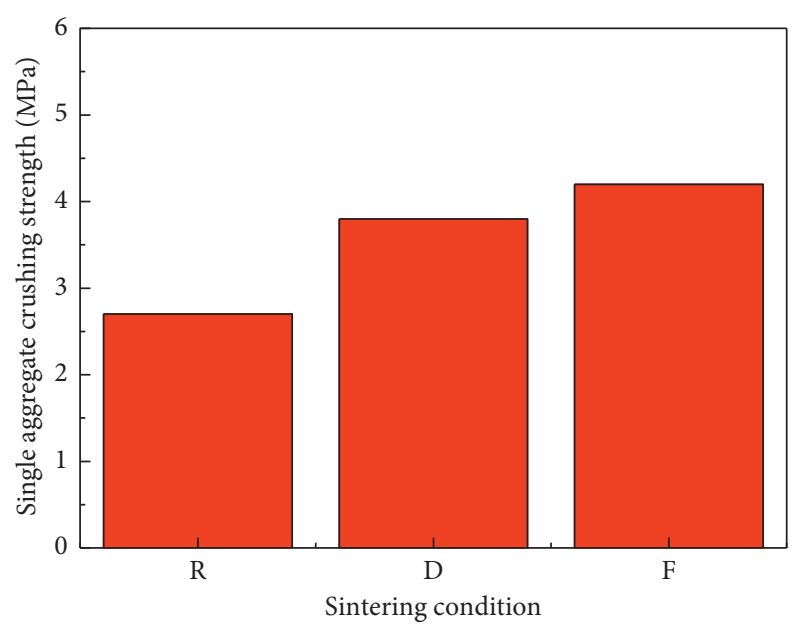

R: rapid sintering at $1180^{\circ} \mathrm{C}$

D: $900^{\circ} \mathrm{C}-1180^{\circ} \mathrm{C}-10 \mathrm{~min}$

F: $600^{\circ} \mathrm{C}-1180^{\circ} \mathrm{C}-30 \mathrm{~min}$

FIgURE 12: Single aggregate crushing strength test result.

(4) The prediction of bloating behaviors in the rotary kiln, a required condition for mass production, was possible, and a bulk density of $1.3 \mathrm{~g} / \mathrm{cm}^{3}$, water absorption ratio of less than $3 \%$, and crushing strength of $4.2 \mathrm{MPa}$ at a temperature lower than $1200^{\circ} \mathrm{C}$ could be achieved.

(5) By graphing the ramping rate, using the least squares method, the black core formation was found with the rate of temperature increase over $27^{\circ} \mathrm{C} / \mathrm{min}$ or over. When the temperature increase rate was $27^{\circ} \mathrm{C} / \mathrm{min}$. or lower, micropore formation was confirmed.

\section{Data Availability}

The data used to support the findings of this study are included within the article.

\section{Conflicts of Interest}

The authors declare that they have no conflicts of interest.

\section{Acknowledgments}

This research was supported by Leading University Project for International Cooperation through the National Research Foundation of Korea (NRF) funded by the Ministry of Education (MOE) (NRF-2017R1D1A1B03035496).

\section{References}

[1] Ministry of Knowledge Economy, The 5th Basic Plan for LongTerm Electricity Supply and Demand, Ministry of Knowledge Economy, Sejong City, Republic of Korea, 2010.

[2] S. H. Kang, K. G. Lee, Y. T. Kim, and S. G. Kang, "Effects of chemicophysical properties of carbon on bloating characteristics of artificial lightweight aggregates using coal ash," Ceramic Transactions Series, vol. 232, pp. 33-42, 2012.

[3] S. J. Lee and T. Y. Lee, "Field tests for the application of bottom ash and shred tire as fill materials," Journal of the Korean Geotechnical Society, vol. 14, pp. 29-37, 2013.

[4] M. Singh and R. Siddique, "Effect of coal bottom ash as partial replacement of sand on properties of concrete," Resources, Conservation and Recycling, vol. 72, pp. 20-32, 2013.

[5] S. J. Kim, "Treatment, disposal, and reuse of contaminated dredged sediment in the ocean," Journal of the Korean Society of Civil Engineers, vol. 55, no. 4, p. 66, 2007.

[6] K. I. Lee, "Recycling of waste as a resource-circulating society building," Geoenvironmental Engineering, vol. 2, no. 1, p. 55, 2001.

[7] B. H. Bae, "Comparison of the country with Busan city in wastes generation and disposal," Journal Korean Society of Environmental Administration, vol. 8, no. 4, p. 409, 2002.

[8] M. Dondi, P. Cappelletti, M. D'Amore et al., "Lightweight aggregates from waste materials: reappraisal of expansion behavior and prediction schemes for bloating," Construction and Building Materials, vol. 127, pp. 394-409, 2016.

[9] O. Arioz, G. Arslan, A. Tuncan, M. Tuncan, G. Kaya, and B. Ash, "Lightweight expanded aggregate production from bottom ash," in Proceedings of the 10th International Conference and Exhibition of the European Ceramic Society, Berlin, Germany, June 2007.

[10] M. J. Quina, M. A. Almeida, R. Santos, J. M. Bordado, and R. M. Quinta-Ferreira, "Compatibility analysis of municipal solid waste incineration residues and clay for producing lightweight aggregates," Applied Clay Science, vol. 102, pp. 71-80, 2014.

[11] Y. C. Liao, C. Y. Huang, and Y. M. Chen, "Lightweight aggregates from water reservoir sediment with added sodium hydroxide," Construction and Building Materials, vol. 46, pp. 79-85, 2013.

[12] C. Yang, C. Cui, and J. Qin, "Recycling of low-silicon iron tailings in the production of lightweight aggregates," Ceramics International, vol. 41, no. 1, pp. 1213-1221, 2015.

[13] Z. Li, H. Zhang, P. Zhao, X. He, and X. Duan, "Manufacturing of ultra-light ceramsite from Slate Wastes in Shangri-la, China," Journal of the Korean Ceramic Society, vol. 55, no. 1, pp. 36-43, 2018.

[14] C. M. Riley, "Relation of chemical properties to the bloating of clays," Journal of the American Ceramic Society, vol. 34, no. 4, pp. 121-128, 1951. 
[15] M. A. Kang and S. Kang, "Effect of activated carbon on bloating properties of artificial lightweight aggregates containing coal reject ash and bottom ash," Journal of the Korean Crystal Growth and Crystal Technology, vol. 23, no. 4, pp. 201-206, 2013.

[16] K. G. Lee, "Bloating mechanism of lightweight aggregate with the size," Journal of the Korean Ceramic Society, vol. 53, no. 2, pp. 241-245, 2016.

[17] K. G. Lee, "Bloating mechanism of artificial lightweight aggregate with reject ash," Journal of the Korean Crystal Growth and Crystal Technology, vol. 22, no. 3, pp. 158-163, 2012.

[18] K. G. Lee, "Bloating mechanism for artificial light weight aggregate of surface modification with coal ash," Journal of the Korean Ceramic Society, vol. 52, no. 2, pp. 159-164, 2015.

[19] C. C. Tsai, K. S. Wang, and I. J. Chiou, "Effect of $\mathrm{SiO}_{2}-\mathrm{Al}_{2} \mathrm{O}_{3}$ flux ratio change on the bloating characteristics of lightweight aggregate material produced from recycled sewage sludge," Journal of Hazardous Materials, vol. 134, no. 1-3, pp. 87-93, 2006.

[20] S. H. Kang and K. G. Lee, "Bloating mechanism of artificial lightweight aggregate for recycling the waste glass," Journal of the Korean Ceramic Society, vol. 47, no. 5, pp. 445-449, 2010.

[21] J. Park, Y. Kim, and Y. Choi, "Property enhancement of lightweight aggregate by carbonation processing," Journal of the Korean Crystal Growth and Crystal Technology, vol. 22, no. 5, pp. 254-259, 2012.

[22] KS F 2304, Method of Test for Plastic Limit of Soil, Korean Standards Association, Seoul, Republic of Korea, 2000.

[23] KS F 2503, Testing Method for Density and Absorption of Coarse Aggregate, Korean Standards Association, Seoul, Republic of Korea, 2007.

[24] J. Park, Y. Kim, K. Lee, S. Kang, and J. Kim, “The mechanism of black core formation," Journal of Korean Crystal Growth and Crystal Technology, vol. 15, no. 5, pp. 208-215, 2005.

[25] K. G. Lee, "Bloating mechanism for coal ash with iron oxide," Journal of the Korean Crystal Growth and Crystal Technology, vol. 24, no. 2, pp. 77-83, 2014.

[26] Y. Kim, Y. Ryu, C. Jang, K. Lee, S. Kang, and J. Kim, “A study on the black core formation of artificial lightweight aggregates at various sintering atmospheres," Journal of the Korean Crystal Growth and Crystal Technology, vol. 19, no. 6, pp. 318-323, 2009.

[27] S. Köse and G. Bayer, "Schaumbildung im system altglas-SiC und die eigenschaften derartiger schaumgläser," Glastechnische Berichte, vol. 55, no. 7, pp. 151-160, 1982.

[28] J. M. Moreno-Maroto and J. Alonso-Azcárate, "What is clay? A new definition of 'clay' based on plasticity and its impact on the most widespread soil classification systems," Applied Clay Science, vol. 161, pp. 57-63, 2018.

[29] G. Cougny, "Spécifications sur les matières premières argileuses pour la fabrication de granulats légers expanses," Bulletin of the International Association of Engineering $\mathrm{Ge}$ ology, vol. 41, no. 1, pp. 47-55, 1990.

[30] E. Fakhfakh, W. Hajjaji, M. Medhioub et al., "Effects of sand addition on production of lightweight aggregates from Tunisian smectite-rich clayey rocks," Applied Clay Science, vol. 35, no. 3-4, pp. 228-237, 2007.

[31] B. González-Corrochano, J. Alonso-Azcárate, and M. Rodas, "Effect of prefiring and firing dwell times on the properties of artificial lightweight aggregates," Construction and Building Materials, vol. 53, pp. 91-101, 2014.

[32] Y. Kanda, S. Sano, F. Saito, and S. Yashima, "Relationships between particle size and fracture energy for single particle crushing [translated]," KONA Powder and Particle Journal, vol. 3, pp. 26-31, 1985.

[33] Y. Li, D. Wu, J. Zhang et al., "Measurement and statistics of single pellet mechanical strength of differently shaped catalysts," Powder Technology, vol. 113, no. 1-2, pp. 176-184, 2000.

[34] Y. M. Wie and K. G. Lee, "Optimum bloating-activation zone of artificial lightweight aggregate by dynamic parameters," Materials, vol. 12, no. 2, 2019. 


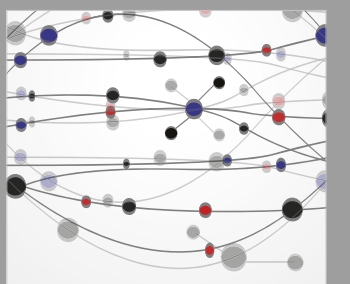

The Scientific World Journal
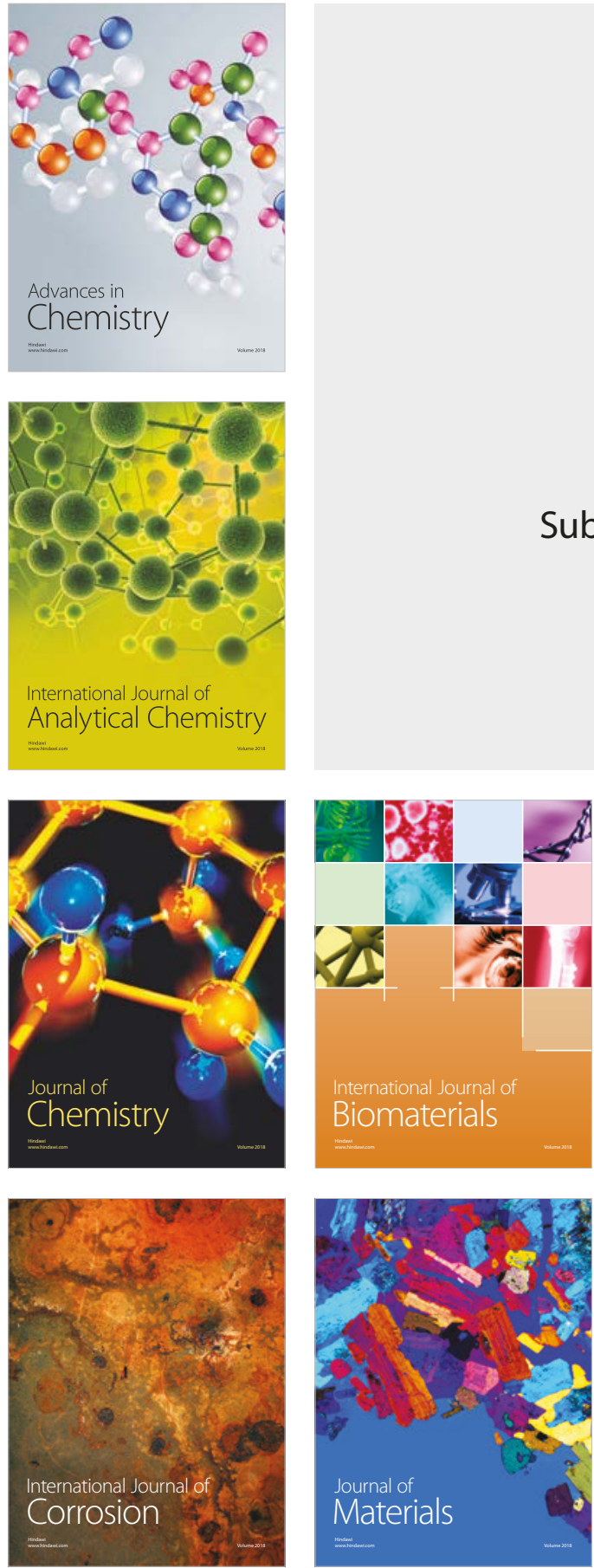

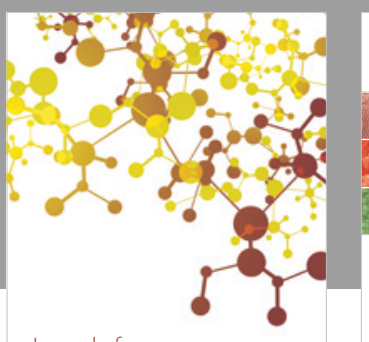

Journal of

Applied Chemistry
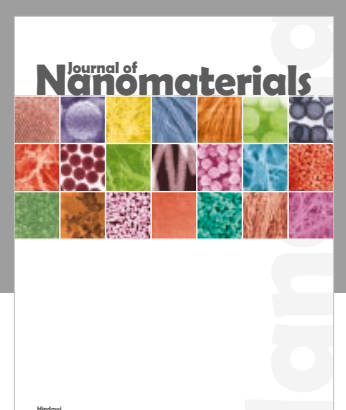

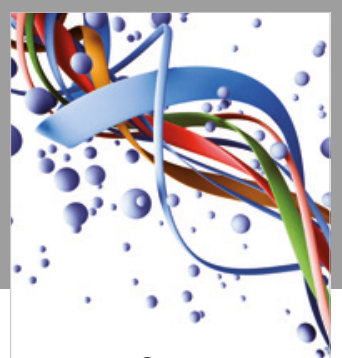

Scientifica

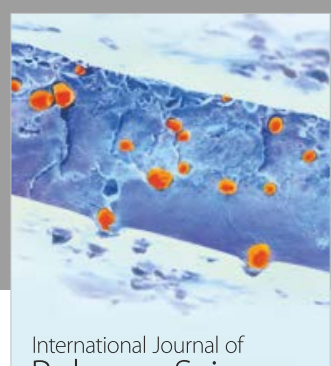

Polymer Science

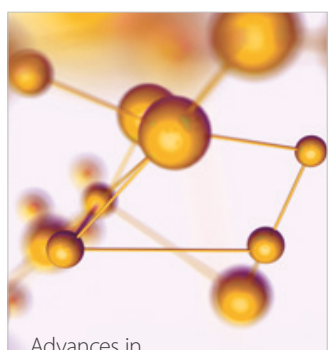

Physical Chemistry
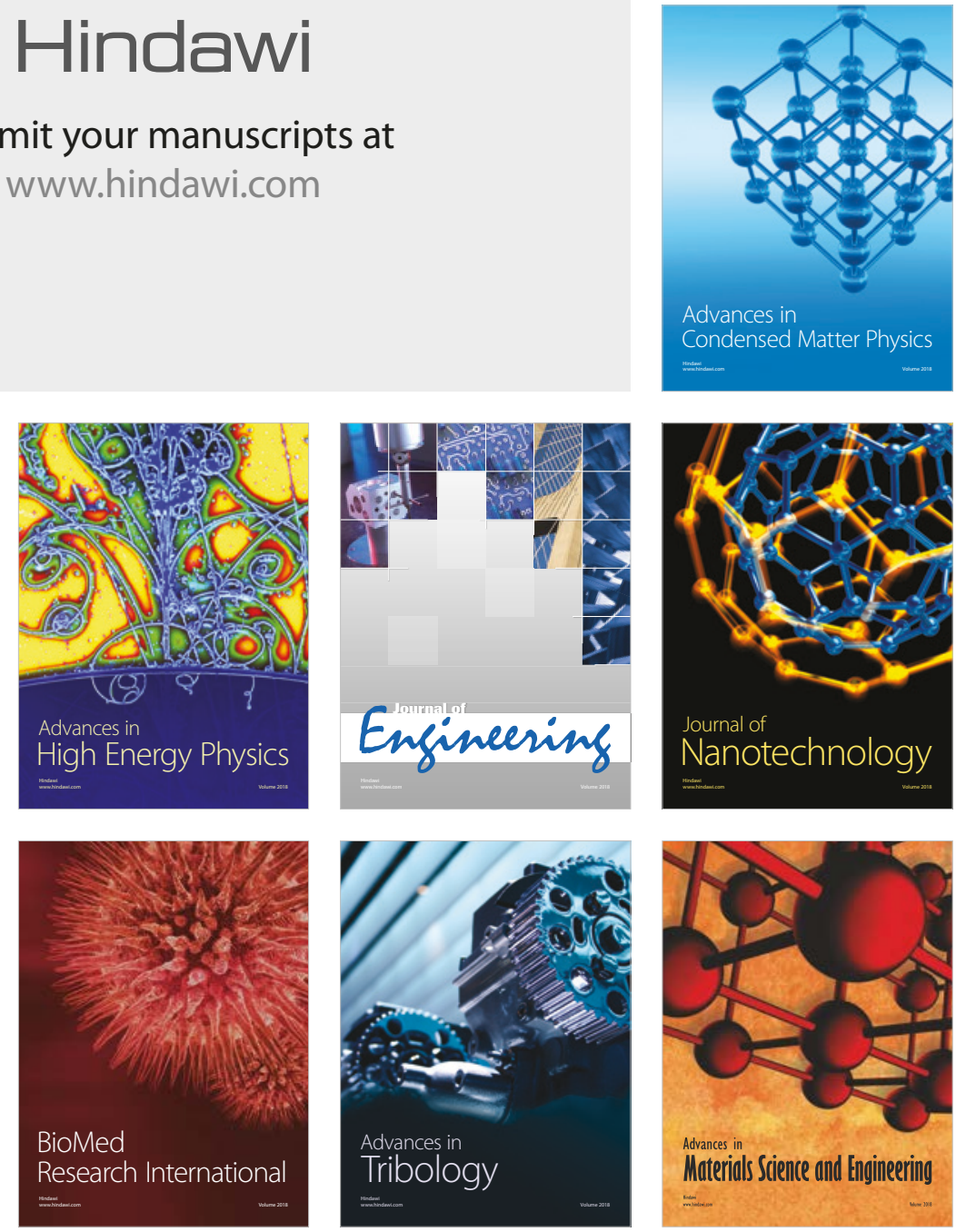